\title{
THE CONSTRUCTION OF A NORMATIVE SCALE OF LOCUS OF CONTROL
}

\author{
JOHANN M SCHEPERS \\ Programme in Industrial Psychology \\ Department of Human Resource Management \\ University of Johannesburg
}

\begin{abstract}
The primary objective of the study was to construct a normative scale of locus of control for use with students and adults. A corollary of the study was to establish the personality, interest and cognitive correlates of locus of control. Conceptually the instrument is based on attribution theory and on social learning theory. The first edition of the Locus of Control Inventory (LCI) was applied to 356 first-year university students during 1994. A factor analysis of the 65 items of the inventory yielded three factors. The factors were interpreted as Autonomy, Internal Control and External Control. Three scales, corresponding to the three factors, were constructed, and yielded reliability coefficients of 0,$80 ; 0,77$ and 0,81 respectively. Following this the cognitive, interest and personality correlates of the LCI were determined. The implications of the findings are discussed.
\end{abstract}

\section{OPSOMMING}

Die hoofdoel van die studie was die konstruksie van 'n normatiewe skaal van lokus van beheer vir gebruik met studente en volwassenes. 'n Newe-doelwit van die studie was om die persoonlikheids-, belangstellings- en kognitiewe korrelate van lokus van beheer te bepaal. Konseptueel is die instrument op attribusieteorie en sosiale-leerteorie gebaseer. Die eerste-uitgawe van die Lokus van Beheervraelys (LvB) is op 356 eerstejaaruniversiteitstudente toegepas gedurende 1994. 'n Faktorontleding van die 65 items van die vraelys is gedoen en het drie faktore opgelewer. Die faktore is as Outonomie, Interne Beheer en Eksterne Beheer geinterpreteer. Voorts is drie skale wat ooreenstem met die drie faktore, gekonstrueer en het betroubaarhede van 0,$80 ; 0,77$ en 0,81 , onderskeidelik, opgelewer. Vervolgens is die kognitiewe, belangstellings- en persoonlikheidskorrelate van die LvB bepaal. Die implikasies van die bevindinge word bespreek.

Since the appearance of Rotter's locus of control questionnaire (1966), called the Internal-External Locus of Control Scale (I-E Scale), numerous other instruments have been published. These instruments vary from general to highly specific. Some of these instruments are intended for children and others for adults. However, they are all concerned with the construct of "locus of control". This construct was created by Rotter and pertains to a person's expectation of reinforcement of his/her behaviour, arising from the social environment. It is therefore theoretically based on social learning theory (Mischel, 1986). Rotter (1966) distinguished between two different orientations in people, namely an internal control orientation and an external control orientation. People with an internal control orientation are convinced that the reinforcement of their behaviour depends on their own achievements, abilities and dedication, whereas people with an external control orientation believe that random or fortuitous events, fate, Lady Luck and certain influential people are responsible for their behaviour.

The most well-known scales in this regard are Rotter's InternalExternal Locus of Control Scale, Wallston's Health Locus of Control Scale (Wallston, Wallston, Kaplin \& Maides, 1976), Wallston's Multidimensional Health Locus of Control Scale (Wallston, Wallston \& De Vellis, 1978), the Nowicki-Strickland Locus of Control Scale (1973), Levenson's Multiple Dimension Locus of Control Scale (1974), the Economic Locus of Control Scale of Furnham (1986) and the Internal Control Index of Duttweiler (1984).

Of the said scales, Rotter's I-E Scale is used most frequently in the USA (69\%), whereas the Nowicki-Strickland Scale as well as the Multiple Dimension Locus of Control Scale of Levenson are used the least $-7 \%$ and $4 \%$ respectively (Procuik \& Lussier, 1975).

The Health Locus of Control Scale, the Multidimensional Health Locus of Control Scale and the Economic Locus of Control Scale are well-developed scales with acceptable reliabilities, but they are too specific for general use.

Requests for copies should be addressed to: JM Schepers, abo@rau.ac.za
The scales of Rotter and Duttweiler are promising scales from a content point of view, but they are both poorly developed from a psychometric point of view. These scales will now be briefly discussed.

The single most important problem regarding Rotter's I-E Scale is the fact that the forced choice item-format leads to ipsative measurement, while the user of the instrument wants to use it in a normative way. In essence, there is nothing wrong with ipsative measures, but the users of such instruments must be fully aware of the limitations thereof.

Ipsative measures can be used successfully to determine the relative strength of drives intra-individually, but not to determine inter-individual differences, for which normative measures are required. Clemans (1966, p. 52) states this as follows: "Ipsative scores are relative scores. It is quite possible that a person obtaining a low ipsative score on a particular trait actually possesses more of the characteristics in question than a person obtaining a much higher ipsative score. It is imperative that users of ipsative variables interpret them in the relative sense only."

Paired comparisons, multiple ranks, forced-choice formats and certain electro-physiological measures, where the instruments are calibrated for each person separately, usually lead to ipsative measurement.

Ipsative measures cannot automatically be subjected to item analysis and factor analysis. If ipsative measures are intercorrelated, more than half of the correlations will be negative and many values will be close to zero (Clemans, 1966, pp. 3, 38 and 51). This will result in a distortion of the factor structure. Tucker (1956, p. 1) explained the problem as follows:

The direct factor analysis approach (termed the R-technique by Stephenson and Cattell) has been properly applied to those measures for which the scale of measurement is consistent for each variable over the population of people. Such measures are termed "normative", and may be illustrated by test scores. The obverse, or Q-technique, factor analysis approach has 
been properly applied to "ipsative" type measures for which the scale of measurement is consistent for each person over the population of observations .... Intercorrelating variables involving ipsative measurement implies the use of a double centered score matrix. Similarly, intercorrelating individuals over observations made by normative measurement implies use of a double centered score matrix. Use of the traditional factor analysis technique involving communalities, however, is not appropriate.

Tucker (1956) developed a special factor analytical technique for this purpose. It is, however, less well known than the standard techniques and not available in packages such as SAS, SPSS and BMDP.

Various attempts to factor analyse Rotter's I-E Scale were doomed to failure because inappropriate factor analytical techniques were used: these include the studies of Rotter (1966), Franklin (1963), Mirels (1970), Abramowitz (1973) and Erwee (1986). However, Collins (1974) was more successful. First, he converted the 23 pairs of the I-E Scale into 46 items with a Likertformat. Then he added 42 items with the connotation that "it depends on the situation". This scale, comprising 88 items, was then applied to 300 undergraduate students. The 46 Likertformat items were then subjected to a principal factor analysis. There were six eigenvalues greater than unity, but only four factors were rotated. The four-factor solution, with a Varimax rotation, produced a fairly neat simple structure. In the light of his four-factor-solution, Collins reached the following conclusion: "A respondent may score external on the Rotter Internal-External Scale because he believes (a) the world is difficult, (b) the world is unjust, (c) the world is governed by luck, or (d) the world is politically unresponsive". However, it cannot be said with certainty that Collins' four-factor-solution represents four factors. It can also be four clusters loading on a single factor.

Duttweiler's Scale (1984) has a good theoretical basis, but its statistical analysis is questionable: she used an intensity scale, but the scale units are not equal. In fact, it is an ordinal scale. She gave no indication of the number of items with which she began, but indicated that she ended with 28 items after item analysis and factor analysis. It seems that she conducted an item analysis with all the items without first establishing the dimensionality of the vector space of the test items. This is emphasised by the fact that she reported only one reliability coefficient (coefficient alpha) for the scale.

In order to establish the dimensionality of her scale, she used principal factor analysis. There were eight eigenvalues greater than unity, but she rotated only two factors - an entirely arbitrary decision. The two factors that were rotated were interpreted as self-confidence and autonomy. There is, however, a strong possibility that these two "factors" are actually two clusters of items loading on the same factor.

There are numerous problems associated with factor analysis of items: a single scale can yield as many as twenty factors, most of which are artefactors. The basic problem here is differential skewness of items. Items with the same degree of skewness or with common content can load on the same factor (cf. Schepers, 1992, pp. 108-143). Therefore, a way must be found to determine the true structure of an intercorrelation matrix of items. This matter will be dealt with in the method section.

In view of the above, it ought to be evident that there is currently not a single locus of control scale that is not contestable. Thus, there is scope for the construction of a new measuring instrument to measure this important construct. The limitations of the said measuring instruments should, however, be overcome ${ }^{1}$ ).

\section{Statement of problem}

The principal objective of the present study was to construct a normative measuring instrument of the construct(s) of locus of control, that can be used with students and adults.

A corollary of the study was to establish the personality, interest and cognitive correlates of locus of control. If important personality, interest and cognitive correlates are found, a single instrument could be used to create a fairly comprehensive personality profile of an individual. Conceptually, the measuring instrument is based on attribution theory and social learning theory.

People are constantly seeking causes for their behaviour and those of others. The ascribed causes of specific behaviour are called attributions. The causative attributions that people make, and their interpretation thereof, determine to a large extent their perceptions of the social world. Is it a friendly or a threatening world? Is it a just or unjust world? Is it a predictable or an unpredictable world? Can we exercise control over particular events through our own abilities or are our lives controlled by certain influential people?

The causes of human behaviour can be divided into two broad categories, namely dispositional causes and situational causes. Dispositional causes pertain to one's natural disposition and include one's organismic attributes. Situational causes pertain to the external world and include all environmental factors (Roediger III, Capaldi, Paris \& Polivy, 1991).

Social learning theory is closely linked to attribution theory: Whilst social learning theory deals with the nature of reinforcements arising from the social environment and how it affects the social behaviour of the learner, attribution theory pertains to the way in which a person gathers information about the stable or invariant characteristics of others - their motives, intentions and traits - as well as of the external world (Baron, Byrne \& Kantowitz, 1980). Rotter's (1966) definition of internal and external control is used throughout this paper.

A construct closely related to internal control is autonomy. Autonomy can be defined as "the tendency to attempt to master or be effective in the environment, to impose one's wishes and designs on it" (Wolman, 1973, p.37). It is expected that persons high on autonomy would seek control of situations that offer possibilities of change, would readily accept the challenge of solving complex problems, would take the initiative in situations requiring leadership, would prefer to work on their own and to structure their own work programme.

With attribution theory and social learning theory as frames of reference, the first edition (1994) of the Locus of Control Inventory (LCI) was constructed. To ensure content validity the domain of locus of control was extensively sampled. Altogether 65 items were written, representing the constructs of Internal Control, External Control and Autonomy.

The items of the LCI are all in the form of questions and the responses are endorsed on a seven-point scale. Only the endpoints of the scales are verbally anchored, and the respondent has to indicate his/her response by drawing a cross in the appropriate box of the rating scale. For large scale testing separate answer sheets, that can be read by an optical page reader, are used.

In the light of the major objective of the study the following postulates and hypothesis were formulated:

\section{Postulate 1}

As far as the structure of the LCI is concerned three factors are postulated, viz. Internal Control, External Control and Autonomy. 
Postulate 2

It is postulated that three homogeneous scales, with acceptable reliabilities, can be formed.

\section{Postulate 3}

It is postulated that two or more contrasting groups can be formed with reference to the measures of the LCI.

\section{Hypothesis 1}

It is hypothesised that the vectors of means of the contrasting groups differ in respect of certain selected measures of cognitive ability, interest and personality.

\section{METHOD}

\section{Participants}

The LCI was applied to a sample of 356 first-year students in industrial psychology at a large South African university where the main language used was Afrikaans. Almost all of the participants were White. The sample was representative of the Faculty of Economic and Business Sciences, as industrial psychology is one of the core subjects in the faculty.

\section{Measuring instruments}

In order to determine the correlates of locus of control the following measuring instruments were applied jointly with the LCI: The General Scholastic Aptitude Test (GSAT), the Senior Aptitude Tests (SAT), the Sixteen Personality Factor Questionnaire (16PF), the Personal, Home, Social and Formal Relations Questionnaire (PHSF), the Survey of Study Habits and Attitudes (SSHA), the 19 Field Interest Inventory (19FII) and the Career Development Questionnaire (CDQ). All the instruments are well known in South Africa and do not need any further description here. Appropriate manuals are available for all the instruments (Cattell, 1989; Claassen, de Beer, Hugo \& Meyer, 1998; Fouché \& Verwey, 1991; Langley, du Toit \& Herbst, 1996). The metrical properties of all the instruments are acceptable for research purposes.

\section{Statistical analysis}

If the presumption exists that the vector space of test items is multidimensional, it will be necessary to first classify the items in terms of the construct measured, before an item analysis is done. The categorisation of the test items can be done with the aid of factor analysis, but the procedure is not free from problems.

The core of the problem centres in the differential skewness of test items. If items that are differentially skew are subjected to factor analysis, a multiplicity of factors is obtained with the result that the true structure of the intercorrelations is obscured (cf. Ferguson, 1941).

To overcome the above-mentioned problem, the following procedure (cf. Schepers, 1992, pp.140-143) was followed in the analysis of the LCI:

1. The 65 items were intercorrelated.

2. The eigenvalues of the unreduced intercorrelation matrix were calculated.

3. As many factors as there were eigenvalues greater than unity were postulated.

4. An iterative principal factor analysis was done.

5. Iteration was done on the number of factors as determined at step 3.

6. The obtained factor matrix was rotated to simple structure by means of a Varimax rotation.

7. All the items with high negative loadings were reflected.

8. All the items with high loadings on a specific factor were added together and a subscore for each factor was computed. Every item was used only once.

9. The obtained subscores were intercorrelated and steps 2 to 4 were repeated.
10.The obtained factor matrix was rotated to simple structure by means of a Direct Oblimin rotation.

11.All subscores with negative loadings on the first principal axis were reflected.

12.Separate scales were formed, corresponding to each of the factors, by grouping all the items together that have substantial loadings on a factor (cf. step 8).

13.Separate item analyses were done for each of the scales formed ${ }^{*}$.

14. Iteration was done in terms of the indices of reliability of the test items.

15. The reliabilities of the scales were determined by means of Cronbach's coefficient alpha.

To determine the correlates of locus of control contrasting groups were used. These groups were formed by using the scores of the LCI. To ensure that the groups that are formed are natural groups, use was made of cluster analysis:

According to Sokal (1974) clusters can be considered as homogeneous classes. Cluster analysis minimises the variance within clusters and maximises the variance between clusters.

The cluster analysis program that was used in the present study is based on a method described by Friedman and Rubin (1967). It comprises an iterative reclassification of objects with the view to minimise the variance within clusters and to maximise the variance between clusters. The largest number of clusters expected (essentially a subjective decision) must be specified ahead of time. The program then forms fewer and fewer clusters until only two are left (Muller, 1975).

Next, the clusters obtained are compared with one another in terms of the reference tests already described. Depending on the number of clusters obtained, MANOVA or Hotelling $\mathrm{T}^{2}$ is used to determine whether the vectors of means of the various clusters differ from one another or not. If the vectors of means of the various clusters differ from one another the group means of the different clusters are compared with one another. For this purpose Tukey's studentised range test or t-tests are used. If there are only two clusters t-tests are used.

\section{RESULTS}

Factor analysis of the LCI

As the procedure that was followed in the analysis of the LCI has been fully described in the method section, only the essential results are given here.

The items of the LCI were intercorrelated, and the eigenvalues of the intercorrelation matrix were calculated. Twenty of the eigenvalues were greater than unity, accordingly 20 factors were extracted and rotated to simple structure by means of a Varimax rotation. These tables, however, are too large for reproduction here. ${ }^{1}$ )

Next, subscores were calculated in respect of each of the factors. The subscores were then intercorrelated and the intercorrelation matrix is given in Table 1. From Table 1 it is clear that the various subscores are mutually correlated despite the fact that the initial factors were orthogonal to one another.

The eigenvalues of the intercorrelation matrix of subscores are given in Table 2. Table 2 shows that six of the eigenvalues are greater than unity. Accordingly six factors were extracted and rotated to simple structure by means of a Direct Oblimin rotation. The rotated factor matrix is given in Table 3 .

From Table 3 it is evident that Factors IV, V and VI are poorly determined with four, one and five items respectively. There are thus only three well determined factors. Separate scales were formed in respect of the three factors. 
Table 1

MATRIX OF INTERCORRELATIONS OF THE SUBTESTS OF THE LOCUS OF CONTROL INVENTORY (1994)

\begin{tabular}{|c|c|c|c|c|c|c|c|c|c|c|c|c|c|c|c|c|c|c|c|c|}
\hline Variable & Subtest 1 & Subtest 2 & Subtest 3 & Subtest 4 & Subtest 5 & Subtest 6 & Subtest 7 & Subtest 8 & Subtest 9 & Subtest 10 & Subtest 11 & Subtest 12 & Subtest 13 & Subtest 14 & Subtest 15 & Subtest 16 & Subtest 17 & Subtest 18 & Subtest 19 & Subtest 20 \\
\hline Subtest 1 & 1,0000 & & & & & & & & & & & & & & & & & & & \\
\hline Subtest 2 & 0,3926 & 1,0000 & & & & & & & & & & & & & & & & & & \\
\hline Subtest 3 & $-0,1092$ & $-0,0682$ & 1,0000 & & & & & & & & & & & & & & & & & \\
\hline Subtest 4 & $-0,0819$ & $-0,0992$ & 0,4227 & 1,0000 & & & & & & & & & & & & & & & & \\
\hline Subtest 5 & $-0,0157$ & $-0,0845$ & 0,3515 & 0,4376 & 1,0000 & & & & & & & & & & & & & & & \\
\hline Subtest 6 & 0,5339 & 0,4607 & $-0,1156$ & $-0,1343$ & $-0,1305$ & 1,0000 & & & & & & & & & & & & & & \\
\hline Subtest 7 & 0,2963 & 0,5332 & $-0,0670$ & $-0,2175$ & $-0,1847$ & 0,3101 & 1,0000 & & & & & & & & & & & & & \\
\hline Subtest 8 & 0,2512 & 0,2612 & $-0,0124$ & $-0,1512$ & $-0,0933$ & 0,3287 & 0,3055 & 1,0000 & & & & & & & & & & & & \\
\hline Subtest 9 & $-0,2305$ & $-0,3677$ & 0,1869 & 0,2377 & 0,2073 & $-0,2259$ & $-0,4142$ & $-0,3604$ & 1,0000 & & & & & & & & & & & \\
\hline Subtest 10 & $-0,1449$ & $-0,0783$ & 0,0787 & 0,0979 & 0,2166 & $-0,1876$ & $-0,0127$ & $-0,0018$ & 0,0345 & 1,0000 & & & & & & & & & & \\
\hline Subtest 11 & 0,3674 & 0,3409 & $-0,1366$ & $-0,1766$ & $-0,0731$ & 0,4013 & 0,2846 & 0,3212 & $-0,2651$ & $-0,0395$ & 1,0000 & & & & & & & & & \\
\hline Subtest 12 & 0,0280 & 0,0400 & 0,1704 & 0,1191 & 0,2731 & $-0,0360$ & 0,0184 & 0,0498 & 0,0744 & 0,0663 & $-0,0125$ & 1,0000 & & & & & & & & \\
\hline Subtest 13 & 0,3652 & 0,3359 & $-0,1394$ & $-0,0771$ & $-0,0557$ & 0,3708 & 0,0925 & 0,1476 & $-0,1664$ & $-0,0318$ & 0,3402 & $-0,0604$ & 1,0000 & & & & & & & \\
\hline Subtest 14 & 0,1650 & 0,1358 & 0,0490 & 0,0465 & 0,0899 & 0,0726 & 0,0560 & 0,0807 & $-0,0237$ & 0,0907 & 0,1356 & $-0,0185$ & 0,1247 & 1,0000 & & & & & & \\
\hline Subtest 15 & 0,0376 & $-0,1172$ & 0,2293 & 0,3555 & 0,2603 & 0,0179 & $-0,2353$ & $-0,1803$ & 0,2567 & $-0,0060$ & $-0,0657$ & 0,0021 & 0,1526 & 0,0137 & 1,0000 & & & & & \\
\hline Subtest 16 & 0,0764 & 0,0143 & 0,0439 & $-0,0365$ & $-0,0382$ & 0,0043 & $-0,0096$ & 0,0389 & 0,0220 & $-0,0219$ & 0,1353 & 0,0401 & 0,0533 & 0,0479 & $-0,0649$ & 1,0000 & & & & \\
\hline Subtest 17 & 0,3290 & 0,2669 & $-0,0326$ & 0,1328 & 0,0445 & 0,1839 & 0,0793 & $-0,0547$ & $-0,0458$ & $-0,1864$ & 0,0871 & 0,0686 & 0,1448 & 0,0713 & 0,0902 & $-0,0458$ & 1,0000 & & & \\
\hline Subtest 18 & 0,1923 & 0,1367 & $-0,0182$ & $-0,0823$ & $-0,1125$ & 0,1269 & 0,0800 & 0,1015 & $-0,1447$ & $-0,0422$ & 0,1441 & $-0,1309$ & 0,1732 & 0,0404 & 0,0427 & 0,0835 & 0,0470 & 1,0000 & & \\
\hline Subtest 19 & $-0,0721$ & $-0,3188$ & 0,0578 & 0,1080 & 0,2381 & $-0,1815$ & $-0,2920$ & $-0,1240$ & 0,2785 & 0,1251 & $-0,0710$ & 0,0744 & $-0,1071$ & 0,0012 & 0,1288 & 0,0022 & $-0,0132$ & $-0,0506$ & 1,0000 & \\
\hline Subtest 20 & 0,2853 & 0,1994 & $-0,1159$ & $-0,0008$ & 0,0228 & 0,2039 & 0,0727 & 0,1427 & $-0,0878$ & $-0,0387$ & 0,2312 & $-0,1792$ & 0,2590 & 0,0468 & 0,0414 & $-0,0164$ & 0,0539 & 0,0598 & $-0,0100$ & 1,0000 \\
\hline
\end{tabular}

Note: $\mathrm{N}=356 ; \mathrm{K}=65$ 
TABLE 2

EIGENVALUES OF UNREDUCED INTERCORRELATION MATRIX $(20 \times 20)$

\begin{tabular}{cc}
\hline ROOT & EIGENVALUE \\
\hline 1 & $\underline{\mathbf{3 , 9 3 1 0}}$ \\
2 & $\underline{\mathbf{2 , 1 7 3 6}}$ \\
3 & $\underline{\mathbf{1 , 5 2 0 5}}$ \\
4 & $\underline{\mathbf{1 , 2 9 9 4}}$ \\
5 & $\underline{\mathbf{1 , 1 1 6 8}}$ \\
6 & $\underline{\mathbf{1 , 0 9 1 3}}$ \\
7 & 0,9841 \\
8 & 0,9044 \\
9 & 0,8534 \\
10 & 0,8260 \\
11 & 0,6885 \\
12 & 0,6642 \\
13 & 0,6073 \\
14 & 0,5689 \\
15 & 0,5547 \\
16 & 0,5340 \\
17 & 0,4816 \\
18 & 0,4594 \\
19 & 0,4130 \\
20 & 0,3277 \\
\hline Trace & 20,000 \\
\hline
\end{tabular}

Next, separate item analyses were done in respect of the three scales. The item statistics in respect of Scale I are given in Table 4. From an inspection of Table 4 it is clear that all the items have acceptable indices of reliability. The item-test correlations vary from 0,389 to 0,638 and the standard deviations from 0,975 to 1,767 . All the items were retained and yielded a Cronbach alpha coefficient of 0,802 . As far as the content of the items are concerned they all deal with autonomous behaviour. The scale was accordingly identified as a scale of Autonomy.
TABLE 4

ITEM STATISTICS IN RESPECT OF SCALE I (AUTONOMY) OF THE LCI

\begin{tabular}{cccccc}
\hline Item & $\mathbf{N}$ & $\begin{array}{c}\text { Mean } \\
\text { of item } \\
\left(\overline{\mathrm{X}}_{\mathrm{g}}\right)\end{array}$ & $\begin{array}{c}\text { Standard } \\
\text { deviation } \\
\text { of item }\left(\mathbf{s}_{\mathrm{g}}\right)\end{array}$ & $\begin{array}{c}\text { Item-test } \\
\text { Correlation } \\
\left(\mathbf{r}_{\mathrm{gx}}\right)\end{array}$ & $\begin{array}{c}\text { Index of } \\
\text { reliability of } \\
\text { item }\left(\mathbf{r}_{\mathrm{gx}} \mathbf{s}_{\mathrm{g}}\right)\end{array}$ \\
\hline${ }^{*} \mathrm{Q} 1$ & 356 & 4,669 & 1,387 & 0,439 & 0,609 \\
$\mathrm{Q} 2$ & 356 & 5,138 & 1,332 & 0,403 & 0,537 \\
$\mathrm{Q} 3$ & 356 & 4,747 & 1,319 & 0,467 & 0,616 \\
$\mathrm{Q} 5$ & 356 & 5,621 & 0,981 & 0,541 & 0,531 \\
${ }^{*} \mathrm{Q} 11$ & 356 & 5,371 & 1,354 & 0,523 & 0,708 \\
$\mathrm{Q} 13$ & 356 & 5,789 & 0,975 & 0,638 & 0,622 \\
$\mathrm{Q} 14$ & 356 & 5,171 & 1,180 & 0,581 & 0,686 \\
${ }^{*} \mathrm{Q} 15$ & 356 & 4,806 & 1,443 & 0,553 & 0,798 \\
$\mathrm{Q} 17$ & 356 & 5,360 & 1,285 & 0,502 & 0,645 \\
$\mathrm{Q} 22$ & 356 & 5,944 & 1,044 & 0,627 & 0,655 \\
$\mathrm{Q} 24$ & 356 & 5,424 & 1,255 & 0,536 & 0,672 \\
$\mathrm{Q} 28$ & 356 & 5,514 & 1,281 & 0,611 & 0,783 \\
$\mathrm{Q} 29$ & 356 & 5,388 & 1,166 & 0,514 & 0,600 \\
$\mathrm{Q} 30$ & 356 & 5,096 & 1,399 & 0,594 & 0,832 \\
${ }^{*} \mathrm{Q} 65$ & 356 & 4,295 & 1,767 & 0,389 & 0,687 \\
\hline
\end{tabular}

Cronbach alpha $=0,802$

Number of items $=15$

*Reflected items

The item statistics in respect of Scale II are given in Table 5 . Table 5 shows that with the exception of item 21 all the items have acceptable indices of reliability. The item-test correlations vary from 0,329 to 0,613 and the standard deviations of the items from 0,834 to 1,843 . Only one item was rejected, namely item 21 . The remaining items yielded a Cronbach alpha coefficient of 0,774 . As far as the content of the items are concerned, it is clear that they deal with the extent of control that the respondent can exert over matters or happenings. The scale was accordingly identified as a scale of Internal Control.

TABLE 3

FACTOR MATRIX OF LCI (DIRECT OBLIMIN ROTATION)

\begin{tabular}{|c|c|c|c|c|c|c|c|}
\hline Variables & $\mathbf{K}$ & FACTOR I & FACTOR II & FACTOR III & FACTOR IV & FACTOR V & FACTOR VI \\
\hline Subtest 1 : Items $6,7,18,19,26,31$ en 37 & 7 & 0,091 & $\underline{0,528}$ & $-0,064$ & 0,322 & 0,205 & 0,145 \\
\hline Subtest 2: Items $2,5,14,22,24,29$ en 30 & 7 & $\underline{0,646}$ & 0,311 & 0,038 & 0,123 & 0,139 & $-0,145$ \\
\hline Subtest 3: Items $12,32,33,35,36$ en 41 & 6 & 0,124 & $-0,198$ & $\underline{0,747}$ & $-0,055$ & 0,045 & 0,188 \\
\hline Subtest 4 : Items $20,43,56,59$ en 64 & 5 & $-0,079$ & 0,052 & $\underline{0,603}$ & $-0,013$ & 0,077 & $-0,185$ \\
\hline Subtest 5: Items $9,47,50,51,57$ en 58 & 6 & $-0,192$ & 0,198 & $\underline{0,379}$ & $-0,238$ & 0,378 & $-0,106$ \\
\hline Subtest 6: Items 27,54 en 55 & 3 & 0,227 & $\underline{0,408}$ & $-0,017$ & 0,295 & 0,038 & 0,197 \\
\hline Subtest 7: Items 13,15 en 28 & 3 & $\underline{0,684}$ & 0,039 & $-0,060$ & $-0,023$ & 0,124 & 0,006 \\
\hline Subtest 8: Items $42,45,46$ en 49 & 4 & 0,326 & 0,165 & $-0,024$ & $-0,127$ & 0,057 & $\underline{0,358}$ \\
\hline Subtest 9: Items 1,11 en 17 & 3 & $-\underline{0,515}$ & $-0,104$ & 0,164 & 0,081 & 0,027 & $-0,041$ \\
\hline Subtest 10: Items 8,52 en 53 & 3 & $-0,009$ & 0,103 & 0,032 & $-\underline{0,507}$ & 0,074 & $-0,082$ \\
\hline Subtest 11: Items 44, 61, 62 en 63 & 4 & 0,130 & $\underline{0,454}$ & $-0,133$ & $-0,008$ & 0,064 & 0,272 \\
\hline Subtest 12: Item 4 & 1 & 0,007 & $-0,137$ & 0,090 & 0,025 & $\underline{0,515}$ & 0,106 \\
\hline Subtest 13: Items 10 en 48 & 2 & 0,023 & $\underline{0,570}$ & $-0,024$ & 0,089 & $-0,108$ & 0,025 \\
\hline Subtest 14: Item 34 & 1 & 0,040 & $\underline{0,226}$ & 0,058 & $-0,082$ & 0,064 & 0,011 \\
\hline Subtest 15: Items 38,39 en 40 & 3 & $-0,282$ & 0,251 & $\underline{0,420}$ & 0,132 & $-0,127$ & $-0,090$ \\
\hline Subtest 16: Item 23 & 1 & $-0,052$ & 0,015 & 0,005 & 0,020 & 0,017 & $\underline{0,235}$ \\
\hline Subtest 17: Item 25 & 1 & 0,044 & 0,185 & 0,023 & $\underline{0,443}$ & 0,266 & $-0,232$ \\
\hline Subtest 18: Items 16 en 21 & 2 & 0,068 & $\underline{0,179}$ & 0,036 & 0,064 & $-0,170$ & 0,116 \\
\hline Subtest 19: Items 3 en 65 & 2 & $-\underline{0,515}$ & 0,098 & $-0,061$ & $-0,096$ & 0,176 & 0,070 \\
\hline Subtest 20: Item 60 & 1 & $-0,015$ & $\underline{0,462}$ & $-0,046$ & $-0,036$ & $-0,121$ & $-0,037$ \\
\hline Number of items per factor & & 15 & 20 & 20 & 4 & 1 & 5 \\
\hline
\end{tabular}


TABLE 5

ITEM STATISTICS IN RESPECT OF SCALE II (INTERNAL CONTROL) OF THE LCI

\begin{tabular}{cccccc}
\hline Item & $\mathbf{N}$ & $\begin{array}{c}\text { Mean } \\
\text { of item } \\
\left(\mathbf{X}_{\mathrm{g}}\right)\end{array}$ & $\begin{array}{c}\text { Standard } \\
\text { deviation } \\
\text { of item }\left(\mathbf{s}_{\mathrm{g}}\right)\end{array}$ & $\begin{array}{c}\text { Item-test } \\
\text { correlation } \\
\left(\mathbf{r}_{\mathrm{gx}}\right)\end{array}$ & $\begin{array}{c}\text { Index of } \\
\text { reliability of } \\
\text { item }\left(\mathbf{r}_{\mathrm{gx}} \mathbf{s}_{\mathrm{g}}\right)\end{array}$ \\
\hline Q6 & 356 & 5,778 & 1,155 & 0,517 & 0,597 \\
Q7 & 356 & 5,542 & 1,116 & 0,424 & 0,473 \\
Q10 & 356 & 6,118 & 0,834 & 0,502 & 0,419 \\
Q16 & 356 & 4,997 & 1,717 & 0,336 & 0,577 \\
Q18 & 356 & 6,132 & 0,870 & 0,530 & 0,461 \\
Q19 & 356 & 6,287 & 0,799 & 0,470 & 0,376 \\
Q21 & 356 & 5,025 & 1,096 & $* * *$ & $* * *$ \\
Q26 & 356 & 5,121 & 1,418 & 0,344 & 0,488 \\
Q27 & 356 & 5,691 & 1,048 & 0,568 & 0,595 \\
Q31 & 356 & 6,101 & 0,956 & 0,555 & 0,531 \\
Q34 & 356 & 5,315 & 1,764 & 0,329 & 0,580 \\
Q37 & 356 & 5,871 & 0,993 & 0,613 & 0,609 \\
Q44 & 356 & 5,149 & 1,025 & 0,497 & 0,510 \\
Q48 & 356 & 4,885 & 1,252 & 0,472 & 0,590 \\
Q54 & 356 & 5,567 & 1,076 & 0,500 & 0,539 \\
Q55 & 356 & 5,612 & 0,926 & 0,561 & 0,520 \\
Q60 & 356 & 5,739 & 1,339 & 0,425 & 0,569 \\
Q61 & 356 & 4,947 & 1,843 & 0,449 & 0,828 \\
Q62 & 356 & 5,008 & 1,255 & 0,408 & 0,513 \\
Q63 & 356 & 6,081 & 0,950 & 0,510 & 0,485 \\
\hline
\end{tabular}

Cronbach alpha $=0,774$

No items were reflected

Number of items $=19$
TABLE 6

ITEM STATISTICS IN RESPECT OF SCALE III (EXTERNAL CONTROL) OF THE LCI

\begin{tabular}{|c|c|c|c|c|c|}
\hline Item & $\mathbf{N}$ & $\begin{array}{c}\text { Mean } \\
\text { of item } \\
\left(\bar{X}_{g}\right)\end{array}$ & $\begin{array}{c}\text { Standard } \\
\text { deviation } \\
\text { of item }\left(s_{g}\right)\end{array}$ & $\begin{array}{c}\text { Item-test } \\
\text { Correlation } \\
\quad\left(\mathrm{r}_{\mathrm{gx}}\right)\end{array}$ & $\begin{array}{c}\text { Index of } \\
\text { reliability of } \\
\text { item }\left(r_{g x} s_{g}\right)\end{array}$ \\
\hline${ }^{*} \mathrm{Q} 9$ & 356 & 5,149 & 1,237 & 0,469 & 0,580 \\
\hline${ }^{*} \mathrm{Q} 12$ & 356 & 2,972 & 1,465 & 0,621 & 0,910 \\
\hline${ }^{*} \mathrm{Q} 20$ & 356 & 3,604 & 1,342 & 0,535 & 0,718 \\
\hline${ }^{*} \mathrm{Q} 32$ & 356 & 3,500 & 1,543 & 0,323 & 0,499 \\
\hline${ }^{*} \mathrm{Q} 33$ & 356 & 2,882 & 1,517 & 0,381 & 0,577 \\
\hline${ }^{*} \mathrm{Q} 35$ & 356 & 3,632 & 1,570 & 0,507 & 0,796 \\
\hline${ }^{*} \mathrm{Q} 36$ & 356 & 3,868 & 1,511 & 0,508 & 0,767 \\
\hline${ }^{*} \mathrm{Q} 38$ & 356 & 3,671 & 1,397 & 0,376 & 0,525 \\
\hline *Q39 & 356 & 3,506 & 1,403 & 0,500 & 0,702 \\
\hline Q40 & 356 & 5,472 & 1,234 & $* * *$ & $* * *$ \\
\hline${ }^{*} \mathrm{Q} 41$ & 356 & 2,924 & 1,470 & 0,633 & 0,930 \\
\hline${ }^{*} \mathrm{Q} 43$ & 356 & 3,826 & 1,681 & 0,462 & 0,776 \\
\hline${ }^{*} \mathrm{Q} 47$ & 356 & 4,649 & 1,435 & 0,378 & 0,543 \\
\hline${ }^{*} \mathrm{Q} 50$ & 356 & 4,202 & 1,416 & 0,338 & 0,479 \\
\hline${ }^{*} \mathrm{Q} 51$ & 356 & 3,803 & 1,341 & 0,487 & 0,653 \\
\hline${ }^{*} \mathrm{Q} 56$ & 356 & 3,444 & 1,510 & 0,576 & 0,870 \\
\hline${ }^{*} \mathrm{Q} 57$ & 356 & 3,848 & 1,408 & 0,601 & 0,846 \\
\hline${ }^{*} \mathrm{Q} 58$ & 356 & 2,329 & 1,513 & 0,413 & 0,624 \\
\hline${ }^{*} \mathrm{Q} 59$ & 356 & 2,677 & 1,523 & 0,445 & 0,678 \\
\hline${ }^{*} \mathrm{Q} 64$ & 356 & 4,590 & 1,665 & 0,472 & 0,785 \\
\hline
\end{tabular}

Cronbach alpha $=0,807$

Number of items $=19$

*Reflected items

TABLE 7

MEANS AND STANDARD DEVIATIONS OF THE VARIOUS CLUSTERS IN RESPECT OF AUTONOMY, INTERNAL CONTROL AND EXTERNAL CONTROL

\begin{tabular}{llccccccc}
\hline Clusters & & $\mathrm{N}$ & \multicolumn{3}{c}{ Means of clusters } & \multicolumn{2}{c}{ Standard deviations of clusters } \\
\cline { 3 - 9 } & & & Autonomy & $\begin{array}{c}\text { Internal } \\
\text { control }\end{array}$ & $\begin{array}{c}\text { External } \\
\text { control }\end{array}$ & $\begin{array}{c}\text { Autonomy } \\
\begin{array}{c}\text { Internal } \\
\text { control }\end{array}\end{array}$ & $\begin{array}{c}\text { External } \\
\text { control }\end{array}$ \\
\hline CLUSTER 1: & LLA $^{+}$ & 171 & 42,7705 & 43,4269 & 53,2342 & 7,6025 & 8,3837 & 8,8477 \\
CLUSTER 2: & HHA- & 185 & 56,6824 & 56,0757 & 47,0106 & 6,7872 & 7,1224 & 10,0947 \\
\hline
\end{tabular}

TABLE 8

SigNIFICANCE OF DIFFERENCES IN MEANS BETWEEN THE TWO CLUSTERS IN RESPECT OF THE GSAT, SAT AND M-SCORE

\begin{tabular}{|c|c|c|c|c|c|c|c|c|c|c|c|c|}
\hline \multirow[t]{2}{*}{ Variables } & \multicolumn{3}{|c|}{ Cluster 1} & \multicolumn{3}{|c|}{ Cluster 2} & \multirow[t]{2}{*}{ Levene F } & \multirow[t]{2}{*}{ DF } & \multirow[t]{2}{*}{$p(F)$} & \multirow[t]{2}{*}{ t-Value } & \multirow[t]{2}{*}{ DF } & \multirow[t]{2}{*}{$p(t)$} \\
\hline & $\bar{X}_{1}$ & $S^{2}{ }_{1}$ & $\mathrm{~N}_{1}$ & $\overline{\mathrm{X}}_{1}$ & $\mathrm{~S}^{2}{ }_{2}$ & $\mathrm{~N}_{2}$ & & & & & & \\
\hline GSAT: VERBAL IQ & 108,9250 & 10,5050 & 120 & 110,7482 & 11,9916 & 139 & 1,93 & $1 ; 257$ & 0,1655 & $-1,29$ & 257 & 0,1976 \\
\hline GSAT: NON-VERBAL IQ & $\underline{108,3833}$ & 11,8451 & 120 & $\underline{112,0504}$ & 12,1883 & 139 & 0,00 & $1 ; 257$ & 0,9634 & $-2,45$ & 257 & $0,0151^{*}$ \\
\hline SAT 1: VERBAL COMPREHENSION & $\underline{17,8417}$ & 3,8018 & 120 & $\underline{19,1583}$ & 3,6836 & 139 & 0,30 & $1 ; 257$ & 0,5836 & $-2,83$ & 257 & 0,0051 * \\
\hline SAT 2: CALCULATIONS & 17,8833 & 5,9736 & 120 & 19,0575 & 5,6296 & 139 & 0,48 & $1 ; 257$ & 0,4877 & $-1,63$ & 257 & 0,1049 \\
\hline SAT 3: DIGUISED WORDS & 19,7833 & 5,4529 & 120 & 19,7482 & 5,4866 & 139 & 0,03 & $1 ; 257$ & 0,8670 & 0,05 & 257 & 0,9589 \\
\hline SAT 4: COMPARISON & 21,7333 & 3,4731 & 120 & 21,4748 & 3,5982 & 139 & 0,20 & $1 ; 257$ & 0,6542 & 0,59 & 257 & 0,5584 \\
\hline SAT 5: PATTERN COMPLETION & $\underline{19,0417}$ & 5,1782 & 120 & $\underline{20,5396}$ & 5,3274 & 139 & 0,38 & $1 ; 257$ & 0,5382 & $-2,29$ & 257 & 0,0231 * \\
\hline SAT 6: FIGURE SERIES & 19,4500 & 4,8764 & 120 & 20,6331 & 4,9346 & 139 & 0,00 & $1 ; 257$ & 0,9526 & $-1,93$ & 257 & 0,0541 \\
\hline SAT 7: SPATIAL 2D & $\underline{17,3167}$ & 5,2724 & 120 & $\underline{20,0719}$ & 5,3238 & 139 & 0,02 & $1 ; 257$ & 0,9019 & $-4,17$ & 257 & $<0,0001$ * \\
\hline SAT 8: SPATIAL 3D & $\underline{18,3833}$ & 4,9742 & 120 & $\underline{19,8489}$ & 4,6077 & 139 & 1,58 & $1 ; 257$ & 0,2103 & $-2,46$ & 257 & $0,0145^{*}$ \\
\hline SAT 9: MEMORY-PARAGRAPH & 13,4333 & 3,6731 & 120 & 13,4604 & 3,7460 & 139 & 0,00 & $1 ; 257$ & 0,9458 & $-0,06$ & 257 & 0,9533 \\
\hline SAT 10: MEMORY-SYMBOLS & 25,6250 & 3,9451 & 120 & 26,1007 & 4,3176 & 139 & 0,01 & $1 ; 257$ & 0,9151 & $-0,92$ & 257 & 0,3584 \\
\hline M-SCORE & 15,2000 & 3,9696 & 120 & 15,9353 & 4,7856 & 139 & 1,47 & $1 ; 257$ & 0,2265 & $-1,33$ & 257 & 0,1837 \\
\hline
\end{tabular}

Hotelling T $2=34,1781$

F-ratio $=2,5063$

$\mathrm{df}=13 \& 24$

$\mathrm{p}=0,0031$ 
The item statistics in respect of Scale III are given in Table 6 . From Table 6 it is clear that with the exception of item 40 all the items have acceptable indices of reliability. The item-test correlations range from 0,323 to 0,633 and the standard deviations of the items from 1,234 to 1,681 . Only one item was rejected, namely item 40 . The remaining items yielded a Cronbach alpha coefficient of 0,807 . As far as the content of the items are concerned they all deal with the degree of control that the external world exerts on the behaviour of the respondent. The scale was accordingly identified as a scale of External Control.

Next, the intercorrelations between the three scales were computed:

The Scale of Autonomy correlates 0,492 with the Scale of Internal Control and both correlate negatively with the Scale of External Control. The Scale of Autonomy correlates $-0,262$ with the Scale of External Control, and the Scale of Internal Control correlates $-0,172$ with External Control. It is therefore evident that Internal Control and External Control are not bipolar opposites, but independent constructs. Although the Scales of Autonomy and Internal Control are moderately correlated, the percentage of common variance is only $24 \%$. Therefore both make a unique contribution in their own right.

Cluster analysis

With the view to doing a cluster analysis of cases (persons) a score was calculated for each participant in respect of each of the three scales of the LCI. To facilitate the interpretation of the scores, the respective scales were linearly transformed to a mean of 50 and a standard deviation of 10 . These transformed scores were then used as iput-variables in the cluster analysis.

There is not an objective criterion for deciding on the number of clusters to take. The choice depends largely on the meaningfulness of the obtained clusters. In the present case two, three and four clusters were considered. Ultimately two clusters were taken. However, four clusters would also have been meaningful.

The means and standard deviations of the two clusters in respect of Autonomy, Internal Control and External Control are given in Table 7. From Table 7 it is clear that Cluster 1 is low in respect of Autonomy and Internal Control and average to high on
External Control. By contrast Cluster 2 is high on Autonomy and Internal Control, but average to low on External Control.

\section{Differences between clusters in respect of the cognitive} measures

The vectors of means of the two clusters were compared with one another in respect of Verbal and Non-verbal IQ (GSAT), the various measures of the Senior Aptitude Tests (SAT) and the Mscore (matric mark). The significance of the differences in means between the various measures are shown in Table 8 .

Table 8 indicates that the Hotelling $\mathrm{T}^{2}$-value is equal to 34,178 with an associated F-ratio of 2,506. This F-value, with 13 and 245 degrees of freedom, is statistically highly significant $(p=0,0031)$. Therefore, the t-tests can be interpreted with confidence.

From Table 8 it is clear that the means of Cluster 2 (HHA-) are statistically significantly higher than those of Cluster $1\left(\mathrm{LLA}^{+}\right)$in respect of the following variables:

- Non-verbal IQ

- Verbal Comprehension

- Pattern Completion

- Spatial 2D

- Spatial 3D

It is therefore clear that persons with high scores on Autonomy and Internal Control and low scores on External Control achieve higher scores on the cognitive measures than those who are low on Autonomy and Internal Control, but high on External Control.

Differences between clusters in respect of the various primary factors of the $16 \mathrm{PF}$

The vectors of means of the two clusters were also compared in terms of the various primary factors of the $16 \mathrm{PF}$. The significance of the differences in means of the two clusters, in respect of the measures mentioned, are given in Table 9 .

Table 9 shows that the Hotelling $\mathrm{T}^{2}$-value is equal to 59,902 with an associated F-value of 3,525. This F-value, with 16 and 242 degrees of freedom, is statistically highly significant $(\mathrm{p}<0,0001)$. Thus, the t-tests can be interpreted with confidence.

TABLE 9

SIGNIFICANCE OF DIFFERENCES IN MEANS BETWEEN THE TWO CLUSTERS IN RESPECT OF THE 16PF

\begin{tabular}{|c|c|c|c|c|c|c|c|c|c|c|c|c|}
\hline \multirow[t]{2}{*}{ Variables } & \multicolumn{3}{|c|}{ Cluster 1} & \multicolumn{3}{|c|}{ Cluster 2} & \multirow[t]{2}{*}{ Levene $\mathrm{F}$} & \multirow[t]{2}{*}{ DF } & \multirow[t]{2}{*}{$\mathrm{p}(\mathrm{F})$} & \multirow[t]{2}{*}{ t-Value } & \multirow[t]{2}{*}{ DF } & \multirow[t]{2}{*}{$p(t)$} \\
\hline & $\overline{\mathrm{X}}_{1}$ & $S^{2}{ }_{1}$ & $\mathrm{~N}_{1}$ & $\overline{\mathrm{X}}_{1}$ & $\mathrm{~S}^{2}{ }_{2}$ & $\mathrm{~N}_{2}$ & & & & & & \\
\hline Factor A: Sociability & 12,8667 & 3,3430 & 120 & 13,1727 & 3,2813 & 139 & 0,00 & 1 and 257 & 0,9676 & $-0,74$ & 257 & 0,4588 \\
\hline Factor B: Intelligence & 7,7833 & 1,6712 & 120 & 7,7842 & 1,7887 & 139 & 0,01 & 1 and 257 & 0,9355 & 0,00 & 257 & 0,9969 \\
\hline Factor C: Emotional Maturity & $\underline{14,7833}$ & 3,4911 & 120 & $\underline{16,0647}$ & 3,8565 & 139 & 2,02 & 1 and 257 & 0,1564 & $-2,79$ & 257 & $0,0057^{*}$ \\
\hline Factor E: Dominance & $\underline{14,1250}$ & 4,2338 & 120 & $\underline{16,0576}$ & 4,8838 & 139 & 2,30 & 1 and 257 & 0,1307 & $-3,38$ & 257 & $0,0009^{*}$ \\
\hline Factor F: Happy-go-lucky & 17,5167 & 4,4983 & 120 & 18,4532 & 5,4324 & 139 & 2,24 & 1 and 257 & 0,1357 & $-1,50$ & 257 & 0,1357 \\
\hline Factor G: Conscientiousness & 12,3333 & 3,2496 & 120 & 13,0576 & 3,8669 & 139 & 1,46 & 1 and 257 & 0,2281 & $-1,62$ & 257 & 0,1071 \\
\hline Factor H: Venturesomeness & $\underline{12,8667}$ & 5,1855 & 120 & $\underline{16,0216}$ & 4,5292 & 139 & 5,08 & 1 and 257 & 0,0250 * & $-5,18$ & 257 & $<0,0001$ * \\
\hline Factor I: Emotional Sensitivity & $\underline{9,8167}$ & 3,5716 & 120 & $\underline{8,8129}$ & 3,8175 & 139 & 0,60 & 1 and 257 & 0,4398 & 2,17 & 257 & $0,0306^{*}$ \\
\hline Factor L: Suspiciousness & 9,5917 & 2,4236 & 120 & 9,3237 & 2,9023 & 139 & 4,67 & 1 and 257 & $0,0316^{*}$ & 0,81 & 257 & 0,4190 \\
\hline Factor M: Imaginativeness & 13,5000 & 3,1940 & 120 & 12,7698 & 3,3886 & 139 & 0,46 & 1 and 257 & 0,4984 & 1,78 & 257 & 0,0769 \\
\hline Factor N: Astuteness & $\underline{10,0250}$ & 2,3424 & 120 & $\underline{10,6331}$ & 2,4968 & 139 & 1,85 & 1 and 257 & 0,1748 & $-2,01$ & 257 & 0,0454 * \\
\hline Factor O: Apprehensiveness & $\underline{12,2583}$ & 3,4287 & 120 & $\underline{10,2230}$ & 3,9874 & 139 & 3,64 & 1 and 257 & 0,0575 & 4,37 & 257 & $<0,0001$ * \\
\hline Factor Q1: Radicalism & $\underline{10,0500}$ & 2,4898 & 120 & $\underline{10,9137}$ & 2,8424 & 139 & 1,71 & 1 and 257 & 0,1924 & $-2,58$ & 257 & 0,0104 * \\
\hline Factor Q2: Self-sufficiency & $\underline{9,7583}$ & 3,3532 & 120 & 8,8849 & 3,5223 & 139 & 0,02 & 1 and 257 & 0,8925 & 2,03 & 257 & 0,0429 * \\
\hline Factor Q3: Self-control & 9,9250 & 2,7960 & 120 & 9,9784 & 3,0443 & 139 & 0,13 & 1 and 257 & 0,7154 & $-0,15$ & 257 & 0,8839 \\
\hline Factor Q4: Tenseness & $\underline{12,8667}$ & 4,0707 & 120 & $\underline{11,1799}$ & 5,1923 & 139 & 9,58 & 1 and 257 & 0,0022 * & 2,93 & 254,7 & $0,0037^{*}$ \\
\hline
\end{tabular}

Hotelling $\mathrm{T}^{2}=59,9021$

F-ratio $=3,5254$

F-ratio $=3,5254$
$\mathrm{df}=16 \& 242$

$\mathrm{p}=<0,0001$ 
From Table 9 it is evident that the two clusters differ statistically significantly from one another in respect of the following primary factors:

- Factor C: Emotional maturity

- Factor E: Dominance

- Factor H: Venturesomeness

- Factor I: Emotional Sensitivity

- Factor N: Astuteness

- Factor O: Apprehensiveness

- Factor Q1: Radicalism

- Factor Q2: Self-sufficiency

- Factor Q4: Tenseness

From Table 9 it is apparent that Cluster $2\left(\mathrm{HHA}^{-}\right)$has higher scores than Cluster $1\left(\mathrm{LLA}^{+}\right)$in respect of the following variables: Emotional maturity, dominance, venturesomeness, astuteness and radicalism. Furthermore, Cluster 2 has lower scores than Cluster 1 in respect of the following variables: Emotional Sensitivity, apprehensiveness and tenseness.

Persons with high scores on Autonomy and Internal Control and low scores on External Control can therefore be described as follows:

They are emotionally stable, mature, calm, self-assertive, independent, unconventional, venturesome, socially uninhibited, firm, responsible, clever, self-assured, analytical, free-thinking, relaxed and composed.

Persons with low scores on Autonomy and Internal Control, and high scores on External Control fall essentially at the opposite pole of all the above-mentioned personality attributes.
Differences between the clusters in respect of the various dimensions of the PHSF Relations Questionnaire

The vectors of means of the two clusters were compared with one another in respect of the various dimensions of the PHSF Relations Questionnaire. The significance of the differences in means between the two clusters are given in Table 10 .

Table 10 shows that the Hotelling $\mathrm{T}^{2}$-value is equal to 101,902 with an associated F-value $(11 \& 247)=8,903$; p < 0,0001). Therefore the t-tests can be interpreted with confidence.

From Table 10 it is clear that the means of the two clusters differ statistically significantly from one another in respect of the following dimensions of the PHSF:

- Self-confidence

- Self-esteem

- Nervousness

- Health

- Personal Freedom

- Sociability - G

- Sociability -S

- Moral Sense

- Formal Relations

With the exception of Self-control and Family Influences the means of Cluster 2 are statistically significantly higher than those of Cluster 1. Persons with high scores on Autonomy and Internal Control, and low scores on External Control are therefore better adjusted persons than those with low scores on Autonomy and Internal Control, and high scores on External Control. This applies to their Personal, Home, Social and Formal relations.

TABLE 10

SigNifiCANCE OF DIFFERENCES IN MEANS BETWEEN THE TWO CLUSTERS IN RESPECT OF THE PHSF

\begin{tabular}{|c|c|c|c|c|c|c|c|c|c|c|c|c|}
\hline \multirow[t]{2}{*}{ Variables } & \multicolumn{3}{|c|}{ Cluster 1} & \multicolumn{3}{|c|}{ Cluster 2} & \multirow[t]{2}{*}{ Levene $\mathrm{F}$} & \multirow[t]{2}{*}{ DF } & \multirow[t]{2}{*}{$\mathrm{p}(\mathrm{F})$} & \multirow[t]{2}{*}{ t-Value } & \multirow[t]{2}{*}{$\mathrm{DF}$} & \multirow[t]{2}{*}{$p(t)$} \\
\hline & $\bar{X}_{1}$ & $S^{2}{ }_{1}$ & $\mathrm{~N}_{1}$ & $\overline{\mathrm{X}}_{1}$ & $\mathrm{~S}^{2}{ }_{2}$ & $\mathrm{~N}_{2}$ & & & & & & \\
\hline PHSF 1: SELF-CONFIDENCE & $\underline{28,3417}$ & 5,2700 & 120 & $\underline{33,6691}$ & 4,7463 & 139 & 0,00 & 1 and 257 & 0,9702 & $-8,56$ & 257 & $<0,0001$ * \\
\hline PHSF 2: SELF-ESTEEM & $\underline{24,6417}$ & 5,2785 & 120 & $\underline{29,4964}$ & 5,5317 & 139 & 0,83 & 1 and 257 & 0,3641 & $-7,19$ & 257 & $<0,0001$ * \\
\hline PHSF 3: SELF-CONTROL & 26,7417 & 5,0117 & 120 & 28,0216 & 5,5995 & 139 & 1,33 & 1 and 257 & 0,2499 & $-1,93$ & 257 & 0,0553 \\
\hline PHSF 4: NERVOUSNESS & $\underline{26,2000}$ & 5,6770 & 120 & $\underline{28,9784}$ & 5,1096 & 139 & 4,71 & 1 and 257 & $0,0309 *$ & $-4,11$ & 257 & 0,0001 * \\
\hline PHSF 5: HEALTH & $\underline{32,3750}$ & 5,4435 & 120 & $\underline{34,5899}$ & 5,8704 & 139 & 0,85 & 1 and 257 & 0,3574 & $-3,13$ & 257 & 0,0019 * \\
\hline PHSF 6: FAMILY INFLUENCES & 29,1167 & 7,8507 & 120 & 30,9065 & 7,6754 & 139 & 0,26 & 1 and 257 & 0,6093 & $-1,85$ & 257 & 0,0652 \\
\hline PHSF 7: PERSONAL FREEDOM & $\underline{33,7417}$ & 7,7095 & 120 & $\underline{36,3309}$ & 7,2145 & 139 & 0,42 & 1 and 257 & 0,5181 & $-2,79$ & 257 & $0,0057^{*}$ \\
\hline PHSF 8: SOCIABILITY-G & $\underline{27,4917}$ & 6,9814 & 120 & $\underline{30,6403}$ & 6,7791 & 139 & 0,25 & 1 and 257 & 0,6191 & $-3,68$ & 257 & 0,0003 * \\
\hline PHSF 9: SOCIABILITY-S & $\underline{29,7250}$ & 7,0006 & 120 & $\underline{32,5180}$ & 7,4856 & 139 & 0,34 & 1 and 257 & 0,5619 & $-3,09$ & 257 & 0,0023 * \\
\hline PHSF 10: MORAL SENSE & $\underline{31,3083}$ & 5,8307 & 120 & $\underline{33,4964}$ & 6,1082 & 139 & 0,04 & 1 and 257 & 0,8347 & $-2,94$ & 257 & $0,0036^{*}$ \\
\hline PHSF 11: FORMAL RELATIONS & $\underline{28,1917}$ & 4,5638 & 120 & $\underline{31,8993}$ & 5,0466 & 139 & 1,46 & 1 and 257 & 0,2277 & $-6,16$ & 257 & $<0,0001$ * \\
\hline
\end{tabular}

Hotelling $\mathrm{T}^{2}=101,9016$

F-ratio $=8,9033$

$\mathrm{df}=11 \& 247$

$\mathrm{p}=<0,0001$

TABLE 11

SIGNIFICANCE OF DIFFERENCES IN MEANS BETWEEN THE TWO CLUSTERS IN RESPECT OF THE SSHA

\begin{tabular}{|c|c|c|c|c|c|c|c|c|c|c|c|c|}
\hline \multirow[t]{2}{*}{ Variables } & \multicolumn{4}{|c|}{ Cluster 1} & \multicolumn{2}{|l|}{ Cluster 2} & \multirow[t]{2}{*}{ Levene $\mathrm{F}$} & \multirow[t]{2}{*}{ DF } & \multirow[t]{2}{*}{$\mathrm{p}(\mathrm{F})$} & \multirow[t]{2}{*}{ t-Value } & \multirow[t]{2}{*}{ DF } & \multirow[t]{2}{*}{$p(t)$} \\
\hline & $\overline{\mathrm{X}}_{1}$ & $\mathrm{~S}^{2}{ }_{1}$ & $\mathbf{N}_{1}$ & $\overline{\mathrm{X}}_{1}$ & $\mathrm{~S}^{2}{ }_{2}$ & $\mathrm{~N}_{2}$ & & & & & & \\
\hline SSHA 1: DELAY AVOIDANCE & $\underline{21,2583}$ & 9,0084 & 120 & $\underline{25,4317}$ & 9,3064 & 139 & 0,47 & 1 and 257 & 0,4940 & $-3,65$ & 257 & 0,0003 * \\
\hline SSHA 2: WORK METHODS & $\underline{24,4833}$ & 7,6191 & 120 & $\underline{29,0935}$ & 8,7534 & 139 & 2,47 & 1 and 257 & 0,1169 & $-4,49$ & 257 & $<0,0001^{*}$ \\
\hline SSSHA 4: EDUCATIONAL APPROVAL & $\underline{25,0500}$ & 8,4822 & 120 & $\underline{27,2518}$ & 8,4176 & 139 & 0,02 & 1 and 257 & 0,8750 & $-2,09$ & 257 & 0,0374 * \\
\hline SSHA 5: ACCEPTANCE OF EDUCATION & 24,7833 & 7,2728 & 120 & 27,4892 & 7,3241 & 139 & 0,15 & 1 and 257 & 0,6998 & $-2,97$ & 257 & 0,0032 * \\
\hline
\end{tabular}

Hotelling $\mathrm{T}^{2}=22,2624$

F-ratio $=5,5006$

$\mathrm{df}=4 \& 254$

$\mathrm{p}=0,0003$ 
Differences between the clusters in respect of the factors of the SSHA

The vectors of means of the two clusters were also compared with one another in respect of the different factors of the SSHA. The significance of the differences between the two clusters are given in Table 11.

Table 11 shows that the Hotelling T2-value is equal to 22,262 with an associated F-value ( $4 \& 254)$ equal to 5,$501 ;(\mathrm{p}=0,0003)$. The t-tests can therefore be interpreted with confidence.

From Table 11 it is clear that the means of the two clusters differ statistically significantly from one another in respect of the following factors of the SSHA:

- Delay avoidance

- Work methods

- Approval of education

- Acceptance of education
Cluster 2 has higher scores than Cluster 1 on all the factors of the SSHA. Persons with high scores on Autonomy and Internal Control, and low scores on External Control, show good adjustment in the educational context: They have good study-habits and work-methods, they avoid postponement, and have a positive attitude toward education.

Differences between the clusters in respect of the factors of the CDQ

The vectors of means of the two clusters were also compared in respect of the different factors of the CDQ. The significance of the differences in means between the two clusters are given in Table 12.

Table 12 shows that the Hotelling $\mathrm{T}^{2}$-value is equal to 30,305 with an associated F-value ( $5 \& 253$ ) equal to 5,967; ( $p<0,0001)$. The t-tests can therefore be interpreted with confidence.

TABLE 12

SIGNIFICANCE OF DIFFERENCES IN MEANS BETWEEN THE TWO CLUSTERS IN RESPECT OF THE CDQ

\begin{tabular}{|c|c|c|c|c|c|c|c|c|c|c|c|c|}
\hline \multirow[t]{2}{*}{ Variables } & \multicolumn{3}{|c|}{ Cluster 1} & \multicolumn{3}{|c|}{ Cluster 2} & \multirow[t]{2}{*}{ Levene $\mathrm{F}$} & \multirow[t]{2}{*}{ DF } & \multirow[t]{2}{*}{$\mathrm{p}(\mathrm{F})$} & \multirow[t]{2}{*}{ t-Value } & \multirow[t]{2}{*}{ DF } & \multirow[t]{2}{*}{$p(t)$} \\
\hline & $\overline{\mathrm{X}}_{1}$ & $S^{2}{ }_{1}$ & $\mathrm{~N}_{1}$ & $\overline{\mathrm{X}}_{1}$ & $\mathrm{~S}^{2}{ }_{2}$ & $\mathrm{~N}_{2}$ & & & & & & \\
\hline CDQ 1: SELF-KNOWLEDGE & $\underline{16,3417}$ & 2,4546 & 120 & $\underline{17,1223}$ & 2,1246 & 139 & 3,34 & 1 and 257 & 0,0686 & $-2,74$ & 257 & $0,0065^{*}$ \\
\hline CDQ 2: DECISION-MAKING & $\underline{15,9083}$ & 3,0348 & 120 & $\underline{17,3741}$ & 2,3196 & 139 & 9,09 & 1 and 257 & $0,0028^{*}$ & $-4,31$ & 220,9 & $<0,0001^{*}$ \\
\hline CDQ 3: CAREER INFORMATION & $\underline{13,6000}$ & 3,7938 & 120 & $\underline{15,1295}$ & 3,4825 & 139 & 1,90 & 1 and 257 & 0,1688 & $-3,38$ & 257 & $0,0008^{*}$ \\
\hline $\begin{array}{l}\text { CDQ 4: INTEGRATION OF SELF- } \\
\text { KNOWLEDGE AND CAREER } \\
\text { INFORMATION }\end{array}$ & $\underline{16,2583}$ & 2,4062 & 120 & $\underline{17,5827}$ & 1,9778 & 139 & 10,33 & 1 and 257 & $0,0015^{*}$ & $-4,79$ & 230,6 & $<0,0001$ * \\
\hline CDQ 5: CAREER PLANNING & $\underline{14,1667}$ & 3,1445 & 120 & $\underline{15,3957}$ & 2,9748 & 139 & 0,94 & 1 and 257 & 0,3340 & $-3,23$ & 257 & $0,0014^{*}$ \\
\hline
\end{tabular}

Hotelling $\mathrm{T}^{2}=30,3053$

F-ratio $=5,9667$

$\mathrm{df}=5 \& 253$

$\mathrm{p}=<0,0001$

TABLE 13

SIGNIFICANCE OF DIFFERENCES IN MEANS BETWEEN THE TWO CLUSTERS IN RESPECT OF THE 19FII

\begin{tabular}{|c|c|c|c|c|c|c|c|c|c|c|c|c|}
\hline \multirow[t]{2}{*}{ Variables } & \multicolumn{3}{|c|}{ Cluster 1} & \multicolumn{3}{|c|}{ Cluster 2} & \multirow[t]{2}{*}{ Levene $\mathrm{F}$} & \multirow[t]{2}{*}{ DF } & \multirow[t]{2}{*}{$\mathrm{p}(\mathrm{F})$} & \multirow[t]{2}{*}{ t-Value } & \multirow[t]{2}{*}{ DF } & \multirow[t]{2}{*}{$\mathrm{p}(\mathrm{t})$} \\
\hline & $\overline{\mathrm{X}}_{1}$ & $S^{2}{ }_{1}$ & $\mathrm{~N}_{1}$ & $\overline{\mathrm{X}}_{1}$ & $\mathrm{~S}^{2}{ }_{2}$ & $\mathrm{~N}_{2}$ & & & & & & \\
\hline FII 1: FINE ARTS & 21,6750 & 10,9323 & 120 & 23,1295 & 12,6931 & 139 & 4,94 & $1 ; 257$ & 0,0271 * & $-0,99$ & 257 & 0,3227 \\
\hline FII 2: CLERICAL & 13,9500 & 9,6344 & 120 & 14,0576 & 8,9651 & 139 & 1,52 & $1 ; 257$ & 0,2194 & $-0,09$ & 257 & 0,9260 \\
\hline FII 3: SOCIAL WORK & $\underline{23,0083}$ & 11,9765 & 120 & $\underline{19,4892}$ & 12,3196 & 139 & 0,26 & $1 ; 257$ & 0,6092 & 2,32 & 257 & $0,0210^{*}$ \\
\hline FII 4: NATURE & 11,0500 & 10,4655 & 120 & 11,6906 & 11,2880 & 139 & 2,21 & $1 ; 257$ & 0,1387 & $-0,47$ & 257 & 0,6380 \\
\hline FII 5: PERFORMING ARTS & 14,3500 & 11,6472 & 120 & 16,1727 & 12,9838 & 139 & 2,27 & $1 ; 257$ & 0,1335 & $-1,18$ & 257 & 0,2386 \\
\hline FII 6: SCIENCE & 13,1417 & 10,3211 & 120 & 15,3309 & 10,8183 & 139 & 0,66 & $1 ; 257$ & 0,4174 & $-1,66$ & 257 & 0,0984 \\
\hline FII 7: HISTORICAL & 15,9000 & 10,2984 & 120 & 15,4101 & 10,7244 & 139 & 0,04 & $1 ; 257$ & 0,8477 & 0,37 & 257 & 0,7092 \\
\hline FII 8: PUBLIC SPEAKING & $\underline{15,9750}$ & 10,7144 & 120 & $\underline{21,3093}$ & 11,8333 & 139 & 0,38 & $1 ; 257$ & 0,5379 & $-3,78$ & 257 & $0,0002^{*}$ \\
\hline FII 9: NUMERICAL & 17,4250 & 10,4017 & 120 & 19,9712 & 11,4607 & 139 & 1,75 & $1 ; 257$ & 0,1871 & $-1,86$ & 257 & 0,0640 \\
\hline FII 10: SOCIABILITY & 34,3083 & 8,1877 & 120 & 35,3525 & 9,3327 & 139 & 1,62 & $1 ; 257$ & 0,2044 & $-0,95$ & 257 & 0,3430 \\
\hline FII 11: CREATIVE THOUGHT & $\underline{27,8333}$ & 8,8492 & 120 & $\underline{32,5755}$ & 8,5930 & 139 & 0,05 & $1 ; 257$ & 0,8294 & $-4,37$ & 257 & $<0,0001$ * \\
\hline FII 12: TRAVEL & 31,5083 & 8,9902 & 120 & 32,7050 & 9,2544 & 139 & 0,00 & $1 ; 257$ & 0,9852 & $-1,05$ & 257 & 0,2940 \\
\hline FII 13: PRACTICAL-FEMALE & 17,2500 & 9,9573 & 120 & 15,4532 & 10,9506 & 139 & 0,76 & $1 ; 257$ & 0,3851 & 1,37 & 257 & 0,1710 \\
\hline FII 14: LAW & $\underline{18,6750}$ & 12,2166 & 120 & $\underline{23,0288}$ & 13,6859 & 139 & 3,03 & $1 ; 257$ & 0,0829 & $-2,68$ & 257 & 0,0078 * \\
\hline FII 15: SPORT & 23,6500 & 12,5749 & 120 & 26,5827 & 12,9609 & 139 & 0,13 & $1 ; 257$ & 0,7174 & $-1,84$ & 257 & 0,0668 \\
\hline FII 16: LANGUAGE & 16,2333 & 10,5899 & 120 & 17,7986 & 12,5682 & 139 & 4,88 & $1 ; 257$ & $0,0280^{*}$ & $-1,09$ & 256,9 & 0,2778 \\
\hline FII 17: SERVICE & 17,9417 & 9,2102 & 120 & 17,1007 & 8,0084 & 139 & 2,90 & $1 ; 257$ & 0,0897 & 0,79 & 257 & 0,4326 \\
\hline FII 18: PRACTICAL-MALE & $\underline{15,1667}$ & 11,4989 & 120 & $\underline{18,2086}$ & 12,7100 & 139 & 0,81 & $1 ; 257$ & 0,3679 & $-2,01$ & 257 & $0,0458^{*}$ \\
\hline FII 19: BUSINESS & 27,3917 & 11,2170 & 120 & 29,6547 & 11,8790 & 139 & 1,40 & $1 ; 257$ & 0,2376 & $-1,57$ & 257 & 0,1180 \\
\hline FII 20: WORK-HOBBY & 14,6750 & 2,5771 & 120 & 14,1439 & 3,0158 & 139 & 0,38 & $1 ; 257$ & 0,5402 & 1,51 & 257 & 0,1321 \\
\hline FII 21: ACTIVE-PASSIVE & 10,5500 & 3,1962 & 120 & 9,8993 & 3,3195 & 139 & 0,21 & $1 ; 257$ & 0,6442 & 1,60 & 257 & 0,1107 \\
\hline
\end{tabular}

Hotelling $\mathrm{T}^{2}=48,605$

F-ratio $=2,1344$

$\mathrm{df}=21 \& 237$

$\mathrm{p}=0,0035$ 
From Table 12 it is evident that the means of the two clusters differ statistically significantly in respect of the following factors of the CDQ:

- Self-knowledge

- Decision-making

- Career information

- Integration of self-knowledge and career information

- Career planning

Cluster 2 has higher scores than Cluster 1 in respect of all the factors. Persons with high scores on Autonomy and Internal Control, and low scores on External Control are generally more career mature than persons with low scores on Autonomy and Internal Control, and high scores on External Control.

\section{Differences between the clusters in respect of the various fields of interest of the 19FII}

The vectors of means of the two clusters were also compared in respect of the various fields of interest of the 19FII. The significance of the differences in means between the two clusters are given in Table 13.

Table 13 shows that the Hotelling $\mathrm{T}^{2}$-value is equal to 48,606 with an associated F-value $(21 \& 237)$ equal to 2,134 ; $(\mathrm{p}=0,0035)$. The t-tests can therefore be interpreted with confidence.

From Table 13 it is clear that the means of the two clusters differ statistically significantly in respect of the following fields of the 19FII:

- Social Work

- Public Speaking

- Creative Thought

- Law

- Practical-male

Cluster 2 has higher scores than Cluster 1 in respect of all the above-mentioned fields except Social Work. Persons with high scores on Autonomy and Internal Control, and low scores on External Control have a very strong interest in Creative Thought.

\section{DISCUSSION}

1. Primary objective of study. As far as the primary objective of the study is concerned, namely to construct a normative scale of locus of control for use with students and adults, the outcome was very positive. The LCI yielded three factors which were interpreted as Autonomy, Internal Control and External Control. Despite the fact that the three scales were quite short they nevertheless yielded acceptable reliabilities. Two contrasting groups (clusters) were formed by using the three scores of the LCI in a cluster analysis. The first cluster was low on Autonomy and Internal Control and average-plus on External Control, and the second cluster was high on Autonomy and Internal Control and average-minus on External Control.

2. The cognitive, interest and personality correlates of locus of control. In comparing the means of the two clusters, statistically significant differences were found in respect of a number of cognitive, interest and personality variables. Cluster 2 was consistently superior to Cluster 1 in respect of Non-Verbal IQ, Verbal Comprehension, Pattern Completion, Spatial 2D and Spatial 3D. As far as personality make-up is concerned, Cluster 2 is emotionally mature, dominant, venturesome, astute and radical. Cluster 1, by contrast, is emotionally sensitive, apprehensive, self-sufficient and tense. As far as Personal, Home, Social and Formal relations are concerned Cluster 2 achieved consistently better scores than Cluster 1. Persons high on Autonomy and Internal Control are therefore better adjusted individuals than those high on External Control.
Cluster 2 also achieved consistently higher scores than Cluster 1 on all the subtests of the SSHA. All the differences were statistically highly significant. Persons high on Autonomy and Internal Control and low on External Control therefore have a very positive attitude towards education.

As far as career development is concerned, Cluster 2 achieved consistently higher scores than Cluster 1 . They have better self-knowledge, are better at decision-making, have better career information and are better at integrating their selfknowledge and career Information. They are also better at career planning. All the differences in favour of Cluster 2 are statistically highly significant.

As far as fields of interest are concerned, Cluster 2 obtained statistically significantly higher mean scores than Cluster 1 in respect of Public Speaking, Creative Thought, Law and Practicalmale pursuits. Cluster 1 obtained a higher score than Cluster 2 on Social Work. However, it should be borne in mind that the sample is only representative of the Faculty of Economic and Business Sciences. The correlates of interest should therefore be examined on a much wider sample.

From the foregoing it is clear that the LCI shows great promise, but needs to be extended in scope, and should be applied to a much larger and more representative sample. In particular it should also be applied to a sample of adults and multicultural groups. The second edition (1995) of the LCI has been revised and extended in scope. It is described in the next article in this publication.

\section{ACKNOWLEDGEMENTS}

I hereby wish to thank all the members of the Statistical consultation Service of the University of Johannesburg for all the hours of computational work done for me. I value it very highly.

A special work of thanks to Annetjie Boshoff and her assistant Afton Walters for the typing of the manuscript. Nobody can type tables better than Annetjie.

\section{REFERENCES}

Abramowitz, S.I. (1973). Internal-External control and socialpolitical activism: A test of the dimensionality of Rotter's Internal-External Scale. Journal of Consulting and Clinical Psychology, 40, 196-210.

Baron, R.A., Byrne, D. \& Kantowitz, B.H. (1980). Understanding behavior (2nd ed.) New York: Holt, Rinehart and Winston.

Cattell, H.B. (1989). The 16 PF: Personality in depth. Champaign, Illinois: Institute for Personality and Ability Testing, Inc.

Claassen, N.C.W., de Beer, M., Hugo, H.L.E. \& Meyer, H. M. (1998). Manual for the General Scholastic Aptitude Test. Pretoria: Human Sciences Research Council.

Clemans, W.V. (1966). An analytical and empirical examination of some properties of ipsative measures. Psychometric Monograph Number 14.

Collins, B.E. (1974). Four components of the Rotter InternalExternal Scale: Belief in a difficult world, a predictable world, a just world, and a politically responsive world. Journal of Personality and Social Psychology, 29, 381-391.

Duttweiler, P.C. (1984). The Internal Control Index: A newly developed measure of locus of control. Educational and Psychological Measurement, 44, 209-221

Erwee, R. (1986). Achievement motivation and locus of control of Black university students. Journal of Industrial Psychology, $12,1-9$.

Ferguson, G.A. (1941). The factorial interpretation of test difficulty. Psychometrika, 6, 323-329.

Fouché, F.A. \& Verwey, F.A. (1991. Manual for the Senior Aptitude Tests. Pretoria: Human Sciences Research Council. 
Franklin R.D. (1963). Youth's expectancies about internal versus external control of reinforcement related to $\mathrm{N}$ variables. Unpublished doctoral dissertation, Purdue University.

Friedman, H.P. \& Rubin, J. (1967). On some invariant criteria to grouping data. Journal of American Statistical Association, 62, 1159-1178.

Furnham, A. (1986). Economic locus of control. Human Relations, 39, 29-43.

Langley, R., du Toit, R. \& Herbst, D.L. (1996). Handleiding vir die Loopbaanontwikkelingsvraelys (LOV). Pretoria: Raad vir Geesteswetenskaplike Navorsing.

Levenson, H. (1974). Activism and powerful others: Distinctions within the concept of internal-external control. Journal of Personality Assessment, 38, 377-383.

Mirels, H.L. (1970). Dimensions of internal versus external control. Journal of Consulting and Clinical Psychology, 34, 226-228.

Mischel, W. (1986). On the interface of cognition and personality: Beyond the person-situation debate. American Psychologist, 34, 740-754.

Muller, M.W. (1975). A comparison of some clustering techniques. Unpublished M.Sc Dissertation. Johannesburg: University of the Witwatersrand.

Nowicki, S., Jr. \& Strickland, B.R. (1973). A locus of control scale for children. Journal of Consulting and Clinical Psychology, 40, 148-154.
Procuik, T.J. \& Lussier, R.J. (1975). Internal-external locus of control: an analysis and bibliography of two years of research (1973-1974). Psychological Reports, 37, 1323-1337.

Roediger III, H.L., Capaldi, E.D., Paris, S.G. \& Polivy, J. (1991). Psychology (3rd ed). New York: Harper Collins Publishers.

Rotter, J.B. (1966). Generalized expectancies for internal versus external control of reinforcement. Psychological Monographs, 80, No. 1 (Whole No. 609).

Schepers, J.M. (1992). Toetskonstruksie: Teorie en praktyk. Johannesburg: RAU-Drukpers.

Sokal, R.R. (1974). Classification: Purposes, principles, progress, prospects. Science, 185, 1115-1123.

Tucker, L.R. (1956). Factor analysis of double centered score matrices. Research Memorandum (RM-56-3). Princeton, N.J.: Educational Testing Service.

Wallston, B.S., Wallston, K.A., Kaplin, G.D. \& Maides, S.A. (1976). Development and validation of the Health Locus of Control (HLC) Scale. Journal of Consulting and Clinical Psychology, 44, 580-585.

Wallston, K.A., Wallston, B.S. \& De Vellis, R. (1978). Development of the Multidimensional Health Locus of Control (MHLC) Scale. Health Education Monographs, 6, 160170.

Wolman, B.B. (1973). Dictionary of behavioural science. New York: Van Nostrand Reinhold Company. 